\title{
Evaluasi Terhadap Implementasi Pendidikan Kristiani dalam Konteks Gereja Kristen Sumba Jemaat Uma Manu
}

\author{
Mefibosed Radjah Pono \\ Universitas Kristen Artha Wacana Kupang \\ Mefibosed505@gmail.com
}

\begin{abstract}
The church has the task of teaching the member of the congregation through Christian Education. Christian Education includes all teaching and learning activities in the church with the aim that members of the congregation can know God and through that knowledge, they can experience life renewal. The implementation of Christian Education must take into account the context in which the church lives. The approach model in Christian Religious Education helps the church to carry out its duties according to the context. This article focuses on the description and analysis of the implementation of the Christian Religious Education approach model in the Christian Church of Sumba, Congregation Uma Manu and offers a Christian Education strategy that is appropriate to the context of the congregation. By using a qualitative approaching in research through observation and in-depth interviews, it is concluded that the implementation of Christian Education with a religious instruction approach is appropriate for the context of this congregation, but strategic efforts are needed in its implementation.
\end{abstract}

Keywords: Christian education; Christian Church of Sumba; church; religious instruction

\begin{abstract}
Abstrak: Gereja memiliki tugas melakukan pengajaran kepada warganya melalui Pendidikan Kristiani (PK). PK mencakup semua aktifitas belajar mengajar dalam gereja dengan tujuan agar warga jemaat dapat mengenal Allah dan melalui pengenalan itu, mereka dapat mengalami pembaruan hidup. Implementasi PK oleh gereja haruslah memperhatikan konteks di mana gereja itu hidup. Model pendekatan dalam PK menolong gereja untuk melakukan tugasnya sesuai dengan konteks. Artikel ini berfokus pada deskripsi dan analisa terhadap implementasi model pendekatan PK dalam Gereja Kristen Sumba Jemaat Uma Manu dan menawarkan strategi PK yang sesuai dengan konteks jemaat. Dengan menggunakan pendekatan kualitatif dalam penelitian melalui observasi dan wawancara mendalam disimpulkan bahwa implementasi PAK dengan pendekatan instruksi religius sudah tepat bagi konteks jemaat ini, namun perlu adanya upaya strategis dalam penerapannya.
\end{abstract}

Kata Kunci: gereja; gereja Kristen Sumba; instruksi religious; pendidikan Kristiani

\section{PENDAHULUAN}

Pendidikan Kristiani adalah tugas penting yang harus dilakukan gereja. Gereja sebagai persekutuan murid-murid Kristus diberi tugas oleh Tuhan Yesus dalam Amanat Agung Matius 28:19-20 untuk melakukan tugas pemuridan. Menurut Nainupu, pemuridan merupakan bagian yang tak terpisahkan dari keseluruhan pelayanan gereja. Karena itu, pemuridan harus dilakukan sebagai suatu usaha yang secara sadar dilakukan oleh dan dari gereja, secara terencana dan secara sistematis 
dengan tujuan agar setiap orang percaya atau anggota gereja dapat memiliki iman yang berakar kuat di dalam Kristus. ${ }^{1}$

Tugas pemuridan yang dilakukan gereja tersebut tidak bisa dipisahkan dari tugas pengajaran kepada mereka yang percaya kepada Kristus. Isi pengajaran itu adalah melakukan segala sesuatu yang telah diperintahkan Yesus kepada mereka. Tugas pengajaran ini dilakukan melalui Pendidikan Kristiani (PK) yang dilakukan oleh gereja. Menurut Hattu², PK mencakup seluruh aktifitas belajar-mengajar di gereja. Semua upaya gereja untuk mendidik dan mengajar umat harus dilihat sebagai bagian yang utuh dari PK. Itu sebabnya mengapa kita perlu memberi perhatian yang sama pada semua upaya mendidik berbagai kelompok usia di gereja, termasuk kelas-kelas katekisasi-baik kelas katekisasi untuk peneguhan sidi maupun untuk persiapan dan selama masa perkawinan-kelompok Penelaahan Alkitab, khotbah, dan lain sebagainya. Pelaksanaan PK di gereja, pada berbagai konteksnya, secara sederhana bertujuan untuk pewarisan nilai-nilai iman Kristen dari generasi ke generasi. Pewarisan nilai-nilai iman ini mengambil bentuk yang berbeda-beda sebagaimana disebutkan di atas. Isi dari proses pewarisan itu lebih banyak ditentukan oleh gereja/sinode setempat yang umumnya menyesuaikan dengan kebutuhan konteks, pada tataran lokal maupun global.

Menurut Sitepu, kehadiran pendidikan sangat penting supaya orang-orang percaya dapat hidup dan mengaplikasikan imannya dalam kehidupan sehari-hari yaitu menjadi terang dan garam di lingkungan di mana mereka beraktifitas. ${ }^{3}$ Demikian pula menurut Tafonao, bahwa gereja memiliki tugas penting dalam mendidik warga jemaat khususnya dalam layanan pendidikan atau pembinaan bagi warga gereja, agar seluruh warga jemaat dapat memiliki pemahaman yang benar tentang hidup dalam kebenaran. ${ }^{4}$ Senada dengan itu, Hutabarat juga mengatakan bahwa gereja dalam tugas mendidiknya mengembangkan pengenalan akan karya Allah agar manusia bertumbuh dalam pengenalannya kepada Kristus yang telah menyelamatkannya. Pertumbuhan akan pengenalan akan Tuhan itu merupakan proses yang terus menerus sepanjang hayat yang berkaitan dengan keberadaan manusia dalam konteksnya. 5 Pengenalan akan Allah melalui pendidikan menurut Bimo Setyo Utomo diharapkan dapat terjadinya transformasi kehidupan. ${ }^{6}$

${ }^{1}$ M. Nainupu, "Pemuridan Melalui Pendekatan Konseling Pastoral," Jurnal Theologia Aletheia, No. 19 Vol. 12, 2017: 91-140

2 Justitia Vox Dei Hattu, Keterkaitan Pendidikan Kristiani di Sekolah dan Gereja, Indonesian Journal of Theology, No. 7 Vo.1, (2019): 25-45

${ }^{3}$ Meri Krisna Dewi Sitepu, Implementasi PAK dalam Masyarakat Majemuk, Asteros: Jurnal Teologi dan Pendidikan Kristen, Vol. 8, No 1, (2020): 1 - 13.

4 Talizaro Tafonao, "Pendidikan Kewirausahaan Bagi Warga Gereja Di Era Digital", Visio Dei: Jurnal Teologi Kristen Vol. 2, No. 1 (2020): 127-146

5 Oditha R Hutabarat, Pedagogi Hati: Model PAK sebagai Pendidikan Politik bagi Warga Gereja di Indonesia, Jurnal Voice of Wesley, Vol 2 No 1 (2018): 1-18

${ }^{6}$ Bimo Setyo Utomo, "( R ) Evolusi Guru Pendidikan Agama Kristen Dalam Mentransformasi Kehidupan Siswa," Dumanis:Jurnal Teologi dan Pendidikan Kristiani, Vol. 1, No. 2 (2017): 1-15 
Mengenai orientasi PK, Hattu ${ }^{7}$ mengatakan bahwa $\mathrm{PK}$ dalam ragam konteksnya, harus berorientasi pada upaya memanusiakan manusia. Dalam upaya memanusiakan manusia ini, maka mengajar (dan belajar), sebagai sebuah aktivitas penting dalam PK, baik di sekolah maupun gereja, harus dilihat bukan semata-mata sebagai sebuah proses mentransfer ilmu, atau sebuah proses inisiasi ke dalam sebuah komunitas, atau upaya meneruskan tradisi (Kristen) ke generasi berikutnya, atau bahkan sebagai upaya untuk mengajarkan seseorang tentang Alkitab dan bagaimana menerapkan teks-teks Alkitab itu dalam kehidupannya sehari-hari saja, melainkan juga sebagai sebuah upaya memaknai ulang, mempertanyakan, menganalisis apa yang dipelajari, dan bahkan menolak apa yang tidak sesuai. Dengan demikian menurut Hattu, materi pembelajaran PK tidak hanya mengakomodasi isi Alkitab dan doktrin/ajaran Kristen, tetapi ia juga membuka diri pada cerita dan pengalaman hidup para partisipan yang mengambil bagian dalam proses pembelajaran.

Karena tugas pengajaran ini sangat penting, maka gereja secara serius perlu melakukan tugas ini dengan baik. Menurut Dabora dan Sagala, gereja perlu menjalankan tugas pedagogisnya, apalagi berhadapan dengan berbagai perubahan sosial. ${ }^{8}$ Namun seringkali dalam praktiknya, pemahaman gereja mengenai Amanat Agung seringkali lebih berorientasi pada tugas pemuridan yaitu upaya kristenisasi, penambahan jumlah anggota dan mendirikan gereja baru. Akibatnya sikap moral dan perilaku bahkan iman anggota jemaat menjadi persoalan. Mereka menjadi Kristen KTP (Kartu Tanda Penduduk) yang beribadah di gereja hanya saat kebaktian hari raya seperti Natal dan Paskah saja, kehidupan yang tidak mencerminkan pola hidup Kristus, bahkan tetap mempraktikan kebiasaan dalam kepercayaan agama suku bagi mereka yang berasal dari agama suku. Hal ini terjadi di Gereja Kristen Sumba (GKS) Jemaat Uma Manu. Keadaan ini menjadi keprihatinan gereja dan menimbulkan pertanyaan, sejauh mana PK telah dilakukan dalam gereja? Apakah PK telah direncanakan, dilaksanakan dan dievaluasi demi tercapainya tujuan PK?

Gereja Kristen Sumba (GKS) Jemaat Uma Manu terletak di wilayah pedalaman Pulau Sumba, tepatnya di Desa Uma Manu, Kecamatan Lewa Tidahu, Kabupaten Sumba Timur, Propinsi Nusa Tenggara Timur. Jemaat ini mandiri sejak 20 November 1991. Jumlah warga jemaatnya sebanyak 2.036 orang yang terdiri dari Anggota sidi sebanyak 692 orang (348 orang laki-laki, 344 orang perempuan), anggota baptis sebanyak 797 orang (341 orang laki-laki, 326 orang perempuan). Ada juga anak anggota jemaat (anak-anak dan dewasa) yang belum dibaptis sebanyak 414 orang (226 orang laki-laki dan 188 orang perempuan) dan anggota simpatisan (berasal dari aliran kepercayaan Marapu tapi belum dibaptis) sebanyak 133 orang (73 orang laki-laki, 60 orang perempuan). Gereja ini terbentuk dari hasil

${ }^{7}$ Justitia Vox Dei Hattu, Keterkaitan Pendidikan Kristiani di Sekolah dan Gereja, Indonesian Journal of Theology, No. 7 Vo.1, (2019): 25-45

${ }^{8}$ Lenda Dabora J.F. Sagala, "Tugas Pedagogis Gembala dalam Menyiapkan Warga Gereja Menghadapi Perubahan Sosial" Evangelikal: Jurnal Teologi Injili dan Pembinaan Warga Jemaat, Volume 4, Nomor 2, (2020): 167-174 
pekabaran Injil terhadap orang Sumba yang masih beraliran Marapu (agama suku asli masyarakat Sumba). Saat ini tinggal tersisa 2 Kepala Keluarga dalam wilayah pelayanan jemaat ini yang masih beraliran Marapu. Gedung gereja yang semula hanya 1 buah, kini sudah ada 7 buah. Ini menunjukan keberhasilan tugas gereja dalam kristenisasi, penambahan jumlah anggota dan pendirian gereja.

Penambahan jumlah anggota gereja rupanya menjadi tantangan tersendiri. Warga jemaat tidak rajin beribadah di hari Minggu atau dalam pelayanan ibadah lainnya, kurangnya kesadaran dalam memberi persembahan, banyaknya kasus pencurian ternak yang dilakukan warga jemaat, perzinahan (kumpul kebo) dan perselingkuhan, lebih suka menghabiskan waktu dan uang untuk urusan adat, pesta dan minuman keras, kurang rajin bekerja padahal ladang cukup subur sehingga angka kemiskinan cukup tinggi.

Banyaknya persoalan moral yang terjadi dalam jemaat ini menimbulkan pertanyaan sejauh manakah implementasi PK dalam gereja ini? Model pendekatan PK apakah yang sedang diimplementasikan dalam gereja ini? Apakah pendekatan PK yang dilakukan sudah tepat dan menjawab kebutuhan jemaat? Untuk itu dalam penelitian ini, penulis akan melakukan evaluasi terhadap pelaksaan PK yang sedang dilakukan GKS Jemaat Uma Manu. Nuh dkk. ${ }^{9}$ pernah melakukan penelitian serupa terhadap implementasi Pendidikan Agama Kristen (PAK) dalam konteks Gereja di GKII Tandang, Semarang. Mereka berfokus pada bentuk-bentuk pelaksanaan PAK dalam jemaat di GKII Tandang yang memberi pengaruh terhadap iman jemaat dan terjadinya kemandirian gereja tersebut. Artikel ini tidak hanya memberikan ulasan terhadap implementasi PK tetapi lebih jauh bertujuan mengevaluasi pendekatan PK yang dilakukan sehingga dapat memberikan sumbangan pemikiran terhadap pelaksanaan PK yang sesuai dengan konteks jemaat.

Terkait evaluasi pelaksanaan PK, Edlin ${ }^{10}$ menegaskan sekedar mengetahui nilai akhir atau hasil dari pertandingan tidak banyak gunanya. Yang kita perlukan yaitu penggambaran yang jelas bagaimana pertandingan itu dimainkan. Jadi dalam evaluasi yang dilakukan dalam terhadap pelaksanaan PK di GKS Jemaat Uma Manu adalah bagaimana proses pelaksanaan PK itu sendiri. Sedangkan mengenai pendekatan terhadap PK, Jack L. Seymour mengelompokkan empat ragam pendekatan, yakni social transformation (transformasi sosial), faith community (komunitas iman), spiritual growth (pertumbuhan spiritualitas), dan religious instruction (instruksi religius). Dalam pendekatan transformasi sosial, PK yang diselenggarakan berorientasi pada upaya untuk mengembangkan kemampuan berpikir dan berefleksi secara kritis, serta mendorong partisipan untuk terlibat dalam aksi-aksi sosial kemanusiaan. ${ }^{11}$ Dalam pendekatan komunitas iman, PK terjadi melalui proses sosialisasi dan interaksi dengan anggota komunitas melalui beragam aktivitas

${ }_{9}$ Semion Nuh, dkk, "Implementasi PAK Konteks di GKII Tandang, Semarang” Pengarah: Jurnal Teologi Kristen, Vol. 1, No. 1, (2019): 1-12

${ }^{10}$ Richard J. Edlin, Hakikat Pendidikan Kristen terj. Yakob Riskihadi dan Yenny Halim (Jakarta: BPK Penabur dan BPK Gunung Mulia, 2015): 289.

11 Jack L. Seymour, ed. Mapping Christian Education (Nashville: Abingdon Press, 1997): 12. 
gerejawi, seperti partisipasi dalam ibadah, bernyanyi dan berdoa bersama, kelompok tumbuh bersama, dan sebagainya. ${ }^{12}$ Dalam pendekatan pertumbuhan spiritual, pendidikan dipahami sebagai proses untuk menolong pertumbuhan seseorang, secara moral, iman, spiritual, karakter, dan sebagainya. ${ }^{13}$ Dalam pendekatan instruksi religius, pendidikan dipahami sebagai usaha sengaja dan terencana untuk mengajarkan pengetahuan dan praktik hidup sebagai orang Kristen. Proses pengajaran ini tidak terjadi dalam bentuk-bentuk yang formal dan kaku, melainkan lebih dipahami sebagai sebuah homemaking, yakni sebuah kerja bersama anggota keluarga. ${ }^{14}$

Terkait evaluasi pelaksanaan PK, Edlin ${ }^{15}$ menegaskan sekedar mengetahui nilai akhir atau hasil dari pertandingan tidak banyak gunanya. Yang kita perlukan yaitu penggambaran yang jelas bagaimana pertandingan itu dimainkan. Jadi dalam evaluasi yang dilakukan dalam terhadap pelaksanaan PK di GKS Jemaat Uma Manu adalah bagaimana proses pelaksanaan PK itu sendiri.

\section{METODE PENELITIAN}

Metode penelitian yang digunakan dalam penelitian ini adalah metode penelitian kualitatif. Menurut Moleong,16 Penelitian kualitatif adalah penelitian yang bertujuan memahami fenomena yang dialami oleh subyek penelitian, misalnya tentang perilaku, motivasi, persepsi, tindakan, dan lain-lainnya. Data-data diperoleh melalui observasi, wawancara mendalam dan penelaahan dokumen. Penulis akan melakukan penelitian terkait implementasi PK dalam jemaat Uma Manu yang sudah dilakukan selama ini. Narasumber adalah warga jemaat, pendeta, majelis jemaat dan pengurus komisi pelayanan dalam gereja. Peneliti juga akan memeriksa dokumen dokumen gereja terkait pelaksanaan pelayanan gereja. Peneliti menggunakan instrumen penelitian sebagai pendoman dalam penelitian. Sedangkan wawancara dilakukan secara terstruktur dengan berpedoman pada pertanyaan penelitian. Peneliti juga melakukan observasi partisipatif di mana peneliti terlibat dengan kegiatan yang diamati17 Sedangkan dokumen gereja digunakan sebagai alat pembuktian kegiatan dan pelaksanaan PK dalam gereja. Dokumen tersebut berguna sebagai bukti untuk pengujian.18 Data yang diperoleh selanjutnya diolah dengan cara dipilih mana yang penting yang dapat dipelajari dan dapat diceritakan kepada orang lain. ${ }^{19}$

\section{HASIL dan PEMBAHASAN}

Berdasarkan hasil penelitian dan analisa data, maka peneliti menemukan beberapa hal terkait implementasi PK dalam jemaat.

12 Ibid, 11

13 Ibid. 20

14 Ibid. 20

15 Richard J. Edlin, Hakikat Pendidikan Kristen terj. Yakob Riskihadi dan Yenny Halim (Jakarta: BPK Penabur dan BPK Gunung Mulia, 2015), 289.

16 Moleong, L.J. Metode Penelitian Kualitatif, Bandung, Remaja Rosda Karya (2010), 7

17 Sugiyono, Metode Penelitian Kombinasi, Bandung: Alfa Beta (2010), 310

18 Moleong, L.J. Metode Penelitian Kualitatif, 217

19 Ibid., 248 


\section{Implementasi PK dalam Jemaat}

Adapun bebera implementasi Pendidikan Kristiani yang sedang dilakukan dalam Jemaat Uma Manu saat ini adalah sebagai berikut:

- Penyampaian khotbah dalam ibadah Minggu yang dilakukan satu kali ibadah.

- Kelas katekisasi bagi remaja dan pemuda terutama bagi mereka yang hendak mengaku percaya (sidi). Kelas katekisasi sangat menekankan aspek kognitif yaitu pengetahuan isi Alkitab. Kelas ini biasanya berlangsung 3 bulan (pada setiap hari Minggu) untuk jemaat dewasa (termasuk yang tidak pernah sekolah dan tidak lulus Sekolah Dasar) dan 6 bulan untuk pelajar. Sebelum dilaksanakan pengakuan percaya (sidi), ada ujian sidi yaitu mengajukan pertanyaan lisan (dialog) sehubungan dengan bahan ajar katekisasi untuk mengetahui pengetahuannya tentang iman Kristen.

- Ibadah-ibadah rumah tangga dilakukan seminggu sekali yang dihadiri oleh anggota jemaat (kecil besar, tua muda) dalam satu lingkungan. Dalam ibadah ini diadakan diskusi dan tanya jawab tentang bahan bacaan Alkitab dan refleksi sehubungan dengan masalah-masalah sosial yang mereka alami. Saat beribadah merupakan saat untuk berkumpul, bercerita tentang kejadian sehari-hari dan saling mengunjungi karena masing-masing orang sibuk dengan pekerjaan sepanjang hari di kebun atau di hutan. Hal ini dimungkinkan karena tersedia banyaknya waktu untuk kesempatan ibadah. Nampak suasana kekeluarga yang sangat erat sepanjang kegiatan beribadah.

- Perlombaan pengetahuan Alkitab (Cerdas Cermat Alkitab) bagi anak-anak dan pemuda dilakukan pada masa perayaan hari raya gerejawi. Melalui kegiatan ini, anak belajar dengan lebih banyak tentang Alkitab.

- Adanya persiapan mengajar bagi para guru sekolah minggu sebelum mengajar pada hari Minggu. Persiapan masih sebatas pada bahan ajar atau bagian Alkitab yang akan diceritakan kepada anak-anak. Kurangnya kreatifitas para pengajar menyebabkan jarangnya dipakai media pembelajaran seperti alat peraga dalam proses pengajaran.

- Pembinaan guru sekolah minggu. Pembinaan ini dilakukan setiap tahun. Pembinaan ini dilakukan sebagai wadah bagi para guru sekolah minggu yang hanya berpendidikan Sekolah Dasar untuk dipersiapkan dan dibekali menjadi pengajar yang baik. Disadari bahwa peranan guru sangat penting dalam model pengajaran religius yaitu yang bertanggung jawab terhadap seluruh proses belajar mengajar.

- Kegiatan komisi pemuda, komisi perempuan dan komisi bapak berfoklus pemahaman Alkitab. Dalam kelompok-kelompok inimereka belajar tentang Alkitab secara bersama-sama, berdiskusi dan mencari maknanya bagi kehidupan pribadi serta berupaya melakukan aksi nyata sebagai wujud dari iman. Mereka menginterpretasikan pengalaman-pengalaman mereka dan hubungkan dengan bagian Alkitab yang dibaca pada saat itu. Dalam diskusi biasanya mereka berusaha menemukan hal yang bisa mereka lakukan 
sehubungan dengan perenungan Firman Tuhan, sebagai aksi nyata saat ini. Muncul aksi-aksi sosial sebagai bentuk kepedulian terhadap saudara-saudara yang lain, misalnya: mengunjungi dan mendoakan yang sakit, membantu orang yang mengalami musibah dan dukacita karena kematian. Muncul juga kepedulian terhadap lingkungan hidup seperti penanaman pohon umur panjang di beberapa lokasi hutan yang gundul dan membersihkan sumber air bersih.

- Pembinaan Majelis Jemaat dan badan pengurus komisi. Kegiatan ini dilakukan dengan maksud agar mereka memahami tugas dan tanggung jawab dalam pelayanan terutama dalam pengajaran gereja.

\section{Analisa terhadap Implementasi PK dalam jemaat}

Dari implementasi PK di atas, dapat dilihat beberapa aspek sehubungan dengan pelaksanaan PK dengan pendekatan instruksi religius menurut Seymor yaitu:

- Penekanan pada aspek kognitif yang nampak pada kegiatan katekisasi dan pengujian sidi, cerdas cermat Alkitab dan pemahaman Alkitab

- Penekanan pada aspek kogintif dan afektif yang nampak pada kegiatan pemahaman Alkitab rumah tangga dan kegiatan komisi-komisi.

- Penekanan pada peranan pengajar yang nampak pada kegiatan pembinaan bagi guru sekolah minggu dan majelis jemaat serta badan pengurus komisi.

- Nampaknya suasana kekeluargaan dalam kegiatan pemahaman Alkitab

- Peranan guru sebagai yang menolong nara didik untuk menghubungkan isi dan praktek iman nampak dalam kegiatan Pemahaman Alkitab, ibadah rumah tangga dan aksi sosial yanng dilakukan.

- Keterlibatan nara didik dalam proses belajar yaitu dalam pemahaman alkitab dan ibadah rumah tangga, terutama saat mereka menceritakan pengalaman (berbicara) dan mendengar penjelasan guru.

Menurut saya, pendekatan instruksi religius yang sedang dipraktekan saat ini tepat bagi Jemaat Uma Manu karena:

- Minimnya pengetahuan warga jemaat tentang pengetahuan Alkitab. Mereka menjadi Kristen setelah penginjilan yang dilakukan kepada mereka. Namun selanjutnya tidak dilakukan pengajaran yang lebih mendalam tentang isi Alkitab. Mereka mendengar cerita Alkitab hanya pada saat mendengarkan khotbah pada hari Minggu (kalau hari Minggu ke gereja) atau pada saat Pemahaman Alkitab atau ibadah lainnya. Itupun tentunya sangat terbatas.

- Belum semua jemaat memiliki Alkitab sehingga mereka tidak bisa membaca Alkitab di rumah sendiri dan mempunyai pengetahuan lebih banyak lagi tentang isi Alkitab.

Penekanan pada pengajaran religius memang memberi kesan bahwa nara didik diisi penuh dengan pengetahuan Alkitab (penekanan pada aspek kognitif). Tetapi jika dipahami lebih jauh, pengajaran ini mencoba menghubungkan iman yang alkitabiah itu dengan kenyataan hidup. Di sinipun terdapat aspek spiritual seorang nara didik yaitu bagaimana dia bersikap sesuai dengan imannya yang alkitabiah itu. Hal yang dikritisi dari pelaksanaan pendekatan pendidikan religius yang dilakukan di jemaat Uma Manu adalah kurang mampunya para pendidik untuk menciptakan 
suasana belajar mengajar yang mendorong nara didik untuk terlibat dalam proses belajar mengajar. Hal ini dapat dipahami karena para pendidik tidaklah berpendidikan khusus teologi. Mereka hanyalah jemaat biasa yang bisa membaca, punya pengetahuan Alkitab, punya keinginan dan merasa terpanggil untuk melayani.

Pendekatan inipun tepat karena ikatan kekeluargaan dalam jemaat masih sangat kuat. Mereka adalah penduduk asli daerah itu, memiliki hubungan persaudaraan yang kuat karena hubungan darah dan terdapat ikatan kekeluargaan yang kuat antara marga/klan yang satu dengan yang lain. Sistem pemukiman berdasarkan hubungan darah masih tetap terpelihara. Satu kampung didiami oleh satu keluarga besar dan marga yang punya hubungan yang sangat dekat. Faktor ini sangat mendukung untuk melaksanakan pendekatan pengajaran religius. Mereka sudah merasakan hubungan kekeluargaan itu sebelum mereka masuk dalam proses belajar mengajar. Dengan terciptanya lingkungan belajar yang nyaman dan menyenangkan, mereka dapat mencintai proses belajar mengajar.

\section{Strategi Pendidikan Kristiani bagi Jemaat Uma Manu}

Dengan memperhatikan konteks Jemaat Uma Manu, maka strategi pendidikan Kristiani berdasarkan pendekatan instruksi religius yang dapat diterapkan dalam jemaat ini adalah sebagai berikut:

\section{Pendataan Keadaan dan Kebutuhan Jemaat Sehubungan dengan Materi Pengajaran}

Menurut Elizabeth Caldwell, salah satu tujuan dari pendekatan pendidikan instruksional adalah menghubungkan antara iman dan kenyataan hidup. ${ }^{20}$ Pendidikan yang dilakukan bertujuan agar jemaat hidup dalam iman yang alkitabiah. Karena itu sangat penting untuk mendata semua keadaan yang sudah, sedang dan akan dialami jemaat, dan hal-hal yang menjadi kebutuhan jemaat. Hal ini berhubungan dengan keadaan awal dalam model "kegiatan didaktis" menurut konsepsi De Corte. ${ }^{21}$ Keadaan awal yang dimaksud De Corte adalah keadaan siswa, guru, jaringan sosial di sekolah dan di kelas, dan faktor-faktor situasional. ${ }^{22}$ Pendataan kebutuhan jemaat ini menolong guru untuk mempersiapkan materi pengajaran yang akan diberikan kepada jemaat dengan baik, menetapkan tujuan pengajaran, mempersiapkan suasana belajar mengajar dan metode yang tepat bagi pengajaran yang sesuai dengan materi pengajaran. Dengan demikian, lewat materi pelajaran yang dipelajari, jemaat dapat menghadapi kenyataan hidup dengan bekal pemahaman isi Alkitab yang benar. Mereka dapat menemukan jalan keluar dari persoalan yang dihadapi dan menghadapinya dengan penuh iman yang alkitabiah. Iman yang bersumber dari pengajaran Alkitab dapat mereka kaitkan atau hidupkan dalam kenyataan hidup.

\section{Pembinaan dan Pelatihan Guru}

Guru yang dimaksud adalah semua yang berperan dalam melakukan pengajaran yaitu Pendeta, Majelis Jemaat, Guru Sekolah Minggu, pemimpin-pemimpin dalam setiap komisi. Seymor mengatakan peranan guru dalam proses pendidikan

${ }^{20}$ Jack Seymour, ed., Mapping Christian Education, (Nashville: Abingdon Press, 1997): 80

${ }^{21}$ W. S. Winkel, Psikologi Pengajaran, (Yogyakarta: Media Abadi, 2005): 52

22 Ibid. 
adalah bertanggung jawab dalam membangun suatu suasana yang menghargai integritas isi, peserta didik, dan praksis, mempertimbangkan seluruh proses belajar, memampukan peserta didik berpikir dan berefleksi terhadap isi alkitabiah dalam terang pengalaman mereka dan memilih suatu cara berada dan cara hidup dalam dunia sebagai respon terhadap panggilan Allah, serta menciptakan visi baru bagi para murid. ${ }^{23}$ Jadi guru berperan dalam upaya membangun suatu suasana dan proses belajar.

Agar dapat menjalankan perannya dengan baik, guru dipersiapkan dengan baik. Ia harus memiliki kemampuan yang memadai bukan hanya dalam penguasaan materi tetapi terutama dalam melakukan proses belajar mengajar. Salah satu caranya adalah dengan melakukan pembinaan dan pelatihan bagi para guru, yang dilakukan oleh pemateri yang cukup handal dan profesional dalam bidang pendidikan. Dalam lingkup jemaat Uma Manu yang sangat terbatas sumber daya manusianya, pembinaan guru sangat diperlukan sehingga ada tenaga pengajar yang bisa melakukan tugas pengajaran dengan baik. Tidak adanya media elektronik yang dapat dipakai sebagai media pembelajaran, menuntut guru harus memiliki kreatifitas dalam menciptakan suasana belajar mengajar, sehingga nara didik dapat merasa nyaman dan tetap mau berada dalam lingkungan pembelajaran.

\section{Pembagian Kelompok Belajar}

Pembagian kelompok dalam kelas pembelajaran merupakan bagian dari proses belajar mengajar model kegiatan didaktis menurut konsep De Corte. ${ }^{24}$ Pembagian kelompok diperlukan agar materi yang diajarkan sesuai dengan keadaan dan kebutuhan kelompok. Misalnya materi kelompok anak tentu berbeda dengan materi kelompok pemuda atau orang dewasa. Hal ini berhubungan dengan penetapan tujuan instruksional. B. S. Bloom dan kawan-kawan membuat suatu klasifikasi (taksonomi) tujuan instruksional dalam ranah kognitif dan afektif sedangkan Simpson menngembangkan tujuan instruksional dalam ranah psikomotorik. ${ }^{25}$ Ranah kognitif, afektif dan psikomotorik setiap kelompok usia tentu berbeda-beda. Dengan pembagian kelompok ini, dapat dipantau sejauh mauh perkembangan kognitif, afektif dan psikomotorik setiap peserta didik. Di sinilah pentingnya pembagian kelas atau kelompok belajar.

\section{Menciptakan Komunitas Pembelajaran dengan Suasana Kekeluarga (Homemaking)}

Seymour menyatakan bahwa pembelajaran haruslah menciptakan suasana yang baik yaitu suasana kekeluargaan (homemaking). Suasana kekeluargaan ini memiliki karakteristik antara lain:

a) Menghargai suasana belajar

b) Suatu iklim harapan untuk pertumbuhan dan pertanggungjawaban.

c) Saling belajar.

d) Proses belajar yang bersifat eksperiensial.

${ }^{23}$ Seymour, ed., Mapping, 81-82

24 Winkel, Psikologi Pengajaran, 52

25 Ibid., 272-274 
Proses mengajar dan belajar dapat direncanakan sehingga orang dewasa tidak hanya mendengar isi tapi juga diperlengkapi untuk menanggapi pelayanan dalam dunia. Melalui ibadah, misi dan pengajaran yang formal dan non formal, jemaat menunjukan komitmen dengan memampukan orang untuk merasa kerasan (seperti di rumah) dalam iman Kristen. ${ }^{26}$ Suasana pembelajaran seperti inilah yang akan diberikan kepada setiap orang yang terlibat dalam proses pembelajaran. Suasana nyaman seperti ini yang membuat orang ingin untuk belajar terutama dalam kalangan jemaat Uma Manu yang dapat dikatakan "jauh” dari suasana sekolah.

Model pembelajaran yang dilakukan selama ini di Uma Manu mengikuti model pendidikan konvensional. Model pendidikan konvensional sangat menekankan bagaimana guru "mengisi" murid dengan pelajaran. ${ }^{27}$ Model ini menjadi sangat membosankan bagi para murid dan menempatkan guru sebagai yang menguasai tanpa adanya suasana saling belajar. Dengan suasana kekeluargaan dalam proses pembelajaran, nara didik akan merasa lebih mencintai proses pembelajaran.

\section{Melakukan Refleksi Isi Alkitab dalam Terang Pengalaman Pribadi untuk Menciptakan Visi}

Salah satu tugas guru dalam pengajaran religius menurut Seymour adalah memampukan peserta didik berpikir dan berefleksi terhadap isi alkitabiah dalam terang pengalaman mereka, dan memilih suatu cara berada dan cara hidup dalam dunia sebagai respon terhadap panggilan Allah. ${ }^{28}$ Merefleksikan isi Alkitab berdasarkan pengalaman pribadi menjadi suatu kegiatan yang sangat bermanfaat. John Dewey, seorang filsuf dan pendidik Amerika, menekankan pentingnya sistem belajar lewat pengalaman (learning by doing). ${ }^{29}$ Keyakinan bahwa semua pendidikan sejati terjadi lewat pengalaman, tidak berarti bahwa semua pengalaman sungguh-sungguh atau sama-sama bersifat edukasi. ${ }^{30}$ Oleh karenanya, sekolah harus memberikan "bahan pelajaran" pengalaman-pengalaman yang berfaedah demi hari depan anak didik dan sekaligus pengalaman itu merupakan hal yang dapat dialami anak didik pada masa sekarang ini. ${ }^{31}$ Berdasarkan pengalaman-pengalaman yang ada, seorang anak didik dapat merefleksikan isi Alkitab. Ia akan menemukan apakah perbuatannya itu benar sesuai dengan yang diinginkan Tuhan dalam Alkitab. Jika tidak, maka ada keputusan untuk melakukan aksi baru sesuai dengan hasil refleksi terhadap Firman Tuhan.

Dalam upaya refleksi berdasarkan pengalaman maka dapat dipakai model Shared Christian Praxis (SCP) atau Berbagi Praksis Kristen menurut Thomas Groome. Model SCP memiliki lima pergerakan yaitu ${ }^{32}$ :

26Seymour, Mapping, 85-86.

27 Stanley Tjahyadi, Pendidikan Spiritual: Suatu Pendekatan Baru bagi Pendidikan Kristiani”. Dalam Tim Penyusun Buku dan Redaksi BPK Gunung Mulia (ed), Memperlengkapi bagi Pelayanan dan Pertumbuhan, (Jakarta: BPK Gunung Mulia dan STT Jakarta, 2002), h. 281.

28 Ibid., 82

${ }^{29}$ Ibid., xiii

${ }^{30}$ Ibid., 12

31 Ibid., xii

32 Thomas H Groome, Sharing Faith: A Comprehensive Approach to Religious Education and Pastoral Ministry: The Way of Shared Praxis,(San Fransisco: Harper San Fransisco, 1991): 146-148. 
- Pergerakan 1: Menamai/mengekspresikan "praksis sekarang"

- Pergerakan 2: Refleksi kritis kepada tindakan sekarang.

- Pergerakan 3: Membuat cerita dan visi Kristen yang mudah dijangkau

- Pergerakan 4: Dialektikal hermeneutik kepada cerita/visi Kristen kepada cerita/visi partisipan

- Pergerakan 5: Keputusan/respon kepada Iman Kristen yang dihidupi.

Lewat model SCP ini, anak didik dapat menceritakan pengalaman mereka yang dialami dalam kehidupan sehari-hari sesuai tema yang disiapkan guru dan menganalisanya penyebab pengalaman itu terjadi. Setelah menganalisa, mereka membaca bagian Alkitab bersama dan guru melakukan hermeneutik terhadap bagian Alkitab agar menemukan pesan teks Alkitab. Pesan teks ini didialogkan dengan pengalaman anak didik (direfleksikan). Kemudian ada keputusan yang diambil untuk tindakan selanjutnya. Topik-topik yang diangkat dan dibahas adalah berhubungan dengan masalah-masalah sosial yang dihadapi seperti pencurian, perzinahan, kekerasan dalam rumah tangga, perjudian dan sebagainya.

\section{Melakukan Pembinaan Sehubungan dengan Berbagai Masalah Sosial}

Pembinaan adalah bagian dari pembelajaran. Pembinaan ini dilakukan dengan melibatkan orang-orang yang handal dalam mengurus persoalan sosial. Misalnya masalah pencurian, dapat melibatkan pihak kepolisian. Masalah kekerasan dalam rumah tangga terhadap anak dan perempuan, dapat melibatkan Komisi Perlindungan Anak dan Bagian Pemberdayaan Perempuan (di pemerintah kabupaten). Pembinaan-pembinaan seperti ini diharapkan menumbuhkan kesadaran dan pemahaman baru untuk dapat melakukan yang terbaik dalam hidup.

\section{Melakukan Refleksi Teologis (dalam Proses Pembelajaran)}

Salah satu model refleksi teologis yang dapat dilakukan sebagai proses pembelajaran ini adalah refleksi teologis model feminis. Refleksi teologis model feminis merupakan refleksi yang komprehensif dan bertujuan untuk membebaskan komunitas manusia, khususnya kemiskinan, dalam hubungan yang harmoni dengan bumi dari batasan dan pengrusakan struktur sosial dan politik. Hal ini nampak pada teologi pembebasan di Amerika Utara yang tidak hanya berfokus pada pembebasan perempuan tapi juga laki-laki dan membebaskan bumi dari eksploitasi. ${ }^{33}$ Anne Carr mendeskripsikan pergerakan refleksi teologis model feminis yaitu ${ }^{34}$ :

1. Kritik terhadap pengalaman dan kondisi perempuan di mana pun dalam dunia pada saat ini.

2. Kritikan ini memimpin kepada tinjauan tradisi Kristen sebagai tafsiran dari prespektif pengalaman perempuan

3. Tinjauan tradisi Kristen untuk membuka kembali hal yang telah dilupakan, yang didevaluasi atau ditekan dari contoh perempuan dan prespektif perempuan di dalam tradisi itu sendiri

${ }^{33}$ Robert L. Kinast, What Are They Saying About Theological Reflection, (New York: Paulist Press, 2000): 27

${ }^{34}$ Ibid, 28 
4. Penafsiran kembali kekristenan yaitu terjemahan ke dalam usulan baru untuk memahami dan mempraktekannya.

Refleksi teologis model ini dilakukan ketika berhadapan dengan kenyataan persoalan sosial yang terjadi di jemaat Uma Manu seperti masalah kemiskinan, kekerasan dalam rumah tangga, kekerasan terhadap anak, masalah yang diakibatkan poligami, dan kerusakan lingkungan hidup. Dengan refleksi ini diharapkan terjadi perubahan sikap dan ada tindakan praksis baru yang dilakukan untuk merubah kehidupan menjadi lebih baik.

Praksis yang dimaksudkan refleksi teologis model feminis adalah emansipasi dan transformasi bagi laki-laki dan perempuan serta dunia yang menopang mereka. Pertama dan yang sangat mendesak, teologi feminis berkomitmen untuk emansipasi perempuan dari dominasi laki-laki dalam semua cara (emosi, fisik, intelektual, pribadi, keuangan, dan lain-lain). Kedua, teologi feminis berkomitmen untuk emansipasi laki-laki dari penyimpangan dan kesalahan jalan dalam hubungan dengan perempuan dan dunia. Ketiga, teologi feminis berkomitmen untuk transformasi sistem, struktur, politik dan institusi yang mengabadikan seksisme dan menghalangi kemajuan perempuan. Keempat, teologi feminis berkomitmen untuk menyelamatkan dunia, untuk membebaskannya dari eksploitasi dan kekuatan irasional yang menghabiskan kekayaan bumi saat ini. ${ }^{35}$

\section{Melakukan Evaluasi terhadap Seluruh Kegiatan Pembelajaran}

Winkel menjelaskan tentang evaluasi yang dimaksud sesuai dengan model kegiatan didaktis menurut konsepsi De Corte dapat diartikan dengan dua cara yaitu: 1) Penilaian terhadap hasil belajar yang telah tercapai, sesuai dengan tujuan instruksional (evaluasi produk), baik dalam aspek isi maupun dalam aspek jenis perilaku; 2) Penilaian terhadap proses belajar mengajar, dengan mengingat tujuan instruksional dan keadaan awal (evaluasi proses). ${ }^{36}$ Dengan evaluasi hasil dan proses, dapat diketahui pencapaian dari seluruh proses pembelajaran sehingga dapat dilakukan langkah baru dalam pengajaran. Jika ada yang belum dicapai atau gagal dan salah dalam proses pembelajaran itu, maka dapat menjadi refleksi untuk diperbaiki dan dicari tahu apa penyebabnya. Diharapkan pada kesempatan pembelajaran selanjutnya, tujuan dapat tercapai atau kesalahan dapat diminimalisir.

\section{KESIMPULAN}

Kegiatan PK dalam gereja perlu memperhatikan konteks di mana gereja itu hidup. Dari hasil temuan dan evaluasi terhadap pelaksanaan PK, maka GKS Jemaat Uma Manu menggunakan pendekatan instruksi religius dalam implementasi PK. Hal ini dilakukan sebagai bagian dari cara gereja untuk menjawab kebutuhan konteks jemaat. Penekanan pada aspek kognitif dan proses pengajaran yang lebih bersifat homemaking adalah aspek yang sangat perlu dilakukan dalam jemaat ini. Meski demikian, pelaksanaan PAK di jemaat ini masih perlu dikembangkan sesuai dengan beberapa strategi yang ditawarkan.

${ }^{35}$ Ibid., 38

36 Winkel, Psikologi Pengajaran, 52 


\section{REFERENSI}

Dabora, Lenda dan J.F. Sagala. “Tugas Pedagogis Gembala dalam Menyiapkan Warga Gereja Menghadapi Perubahan Sosial" Evangelikal: Jurnal Teologi Injili dan Pembinaan Warga Jemaat, Volume 4, Nomor 2, Juli 2020: 167-174

Edlin, Richard J. $\quad$ Hakikat Pendidikan Kristen terj. Yakob Riskihadi dan Yenny Halim (Jakarta: BPK Penabur dan BPK Gunung Mulia, 2015), 289.

Groome, Thomas. Sharing Faith: A Comprehensive Approach to Religious Education and Pastoral Ministry: The Way of Shared Praxis, San Fransisco: Harper San Fransisco, 1991

Hattu, Justitia Vox Dei. "Keterkaitan Pendidikan Kristiani di Sekolah dan Gereja”, Indonesian Journal of Theology, No. 7 Vo.1, Juli 2019: 25-45

Hutabarat, Oditha R. "Pedagogi Hati: Model PAK sebagai Pendidikan Politik bagi Warga Gereja di Indonesia", Jurnal Voice of Wesley, Vol 2 No 1 2018: 1-18

Kinast, L. Robert, What Are They Saying About Theological Relection, New York: Paulist Press, 2000

Moleong, L.J. Metode Penelitian Kualitatif, Bandung, Remaja Rosda Karya, 2010

Nainupu, M. "Pemuridan Melalui Pendekatan Konseling Pastoral," Jurnal Theologia Aletheia, No. 19 Vol. 12, 2017: 91-140

Nuh, Simeon, dkk, "Implementasi PAK Konteks di GKII Tandang, Semarang" Pengarah: Jurnal Teologi Kristen, Vol. 1, No. 1, (2019), 1-12

Seymour, Jack, ed., Mapping Christian Education, Nashville: Abingdon Press, 1997

Sitepu, Meri Krisna Dewi. Implementasi PAK dalam Masyarakat Majemuk, Asteros: Jurnal Teologi dan Pendidikan Kristen, Vol. 8, No 1, Juli 2020: 1 - 13.

Tafonao, Talizaro. "Pendidikan Kewirausahaan Bagi Warga Gereja Di Era Digital", Visio Dei: Jurnal Teologi Kristen Vol.2, No. 1 (2020): 127-146

Tjahyadi, Stanley. Pendidikan Spiritual: Suatu Pendekatan Baru bagi Pendidikan Kristiani”. Dalam Tim Penyusun Buku dan Redaksi BPK Gunung Mulia (ed), Memperlengkapi bagi Pelayanan dan Pertumbuhan, (Jakarta: BPK Gunung Mulia dan STT Jakarta, 2002

Utomo, Bimo Setyo. “(R) Evolusi Guru Pendidikan Agama Kristen Dalam Mentransformasi Kehidupan Siswa," Dumanis (Jurnal Teologi dan Pendidikan Kristiani) Vo. 1, No. 2 (2017): 1-15

Winkel, W. S., Psikologi Pengajaran, Yogyakarta: Media Abadi, 2005. 